\title{
EFEKTIFITAS BIMBINGAN KELOMPOK DENGAN TEKNIK BRAINSTORMING UNTUK MENINGKATKAN KEMAMPUAN PERILAKU ASERTIF SISWA
}

\author{
Dewi Lianasari ${ }^{1)}$, Muhammad Japar ${ }^{2)}$, Purwati $^{3)}$ \\ ${ }^{1)}$ FKIP Universitas Muhammadiyah Magelang, Magelang, Indonesia \\ E-mail: dewilianasari@ummgl.ac.id \\ ${ }^{2)}$ FKIP Universitas Muhammadiyah Magelang, Magelang, Indonesia \\ E-mail: japar@ummgl.ac.id \\ ${ }^{3)}$ FKIP Universitas Muhammadiyah Magelang, Magelang, Indonesia \\ E-mail: bupurwati@ummgl.ac.id
}

\begin{abstract}
Abstrak. Kemampuan berperilaku asertif sangat penting bagi kelangsungan hidup individu di lingkungan sosial. Kemampuan siswa berperilaku asertif baik di lingkungan sekolah, lingkungan keluarga maupun lingkungan sosial menjadi sebuah proses pendewasaan diri dalam menghadapi tuntutan kemajuan zaman dan perkembangan teknologi, sehingga melalui cara berperilaku asertif akan menjadi karakter positif dalam menyampaikan keinginan demi memenuhi kebutuhan hidup sepanjang masa. Tujuan penelitian ini untuk mengetahui pelaksanaan layanan bimbingan kelompok dan mengetahui pengaruh layanan bimbingan kelompok dengan teknik brainstorming untuk meningkatkan perilaku asertif. Penelitian ini menggunakan desain penelitian quasi eksperimen, dengan rancangan pretest-posttest. Para siswa diukur kemampuan perilaku asertif dengan menggunakan skala perilaku asertif. Seluruh subjek penelitian dimasukkan ke dalam satu kelompok yaitu kelompok eksperimen (One Group Pretest-Posttest Design). Hasil penelitian diperoleh bahwa pelaksanaan bimbingan kelompok di SMP Muhammadiyah Alternatif Kota Magelang sudah sesuai dengan tahapan dalam pelaksanaan namun watu pelaksanaan bimbingan kelompok bersifat insidental, hasil uji statistik dengan perhitungan Paired Samples test menunjukkan t-hitung $=-4.640 \leqslant \mathrm{t}$-tabel $=-2.262$, sehingga Ho ditolak dan Ha diterima sehingga dapat disimpulkan bahwa bimbingan kelompok dengan teknik brainstorming terbukti efektif untuk meningkatkan kemampuan perilaku asertif siswa.
\end{abstract}

Kata Kunci: Bimbingan Kelompok; Brainstorming; Perilaku Asertif

\section{PEndahuluan}

Pengembangan generasi muda diarahkan untuk mempersiapkan kader penerus perjuangan bangsa dan pembangunan nasional dengan membekali ketrampilan kepemimpinan, kesegaran jasmani, patriotisme, idealisme, kepribadian dan budi pekerti yang luhur. Perlu diciptakan suasana yang sehat serta usaha-usaha untuk mengembangkan potensi generasi muda sehingga memungkinkan kreativitas generasi muda berkembang secara wajar dan bertanggung jawab.

Remaja (adolescence) merupakan masa transisi atau peralihan dari masa kanak-kanak menuju masa dewasa yang ditandai dengan adanya perubahan aspek psikis, fisik dan psikososial. Secara kronologis yang tergolong remaja ini berkisar antara usia 12/13-21 tahun.

Tugas perkembangan pada masa remaja menuntut perubahan besar dalam sikap dan pola perilaku. Tugas 
perkembangan masa remaja difokuskan pada upaya meninggalkan sikap dan perilaku kekanak-kanakan serta berusaha mencapai kemampuan bersikap dan berperilaku secara dewasa. Tugas-tugas perkembangan masa remaja ini berkaitan dengan perkembangan kognitifnya, kematangan pencapaian perkembangan kognitif akan sangat membantu kemampuan dalam melaksanakan tugas-tugas perkembangan dengan baik [7].

Kenyataan di lapangan remaja memiliki banyak tekanan yang harus dihadapi baik dari teman sebaya atau peer pressure, orang tua, lingkungan serta keadaan.. Tekanan yang paling berat adalah dari teman sebaya, tekanan ini bisa berupa ajakan, rayuan, paksaan untuk ikut melakukan sesuatu yang sebenarnya tidak ingin dilakukan oleh remaja. Bahkan tekanan yang dihadapi oleh remaja seringkali disertai dengan ancaman dan janji yang akan diperoleh bila remaja tersebut mau melakukannya. Remaja khawatir berperilaku asertif atau berbicara terus terang dan apa adanya, karena takut dianggap tidak sopan, arogan atau dapat melukai perasaan orang lain. Namun dalam hal ini remaja dituntut agar mampu bersikap asertif karena salah satu tugas perkembangan remaja adalah mampu mencapai kemandirian emosional.

Sikap asertif merupakan tindakan yang tepat sesuai dengan kata hati dalam menolak sesuatu yang membuatnya tidak nyaman dan ini adalah respon spontan yang positif, tegas, tepat untuk mempertahankan hak dan tujuannya. Seringkali remaja tidak mau dan tidak mampu bersikap asertif. Secara tidak sadar individu bertindak tidak asertif walaupun mungkin bermaksud menghindari situasi tidak nyaman, hal tersebut justru bisa membahayakan hubungan jangka panjang individu dengan individu lain.

Seseorang dapat dikatakan asertif bila ia mampu menegakkan hak-hak pribadi dengan cara mengekspresikan pikiran, perasaan, dan keyakinan yang ada dalam dirinya dengan cara langsung melalui ungkapan verbal yang dilakukan dengan jujur dan dengan cara nyaman, tanpa mengabaikan hak-hak orang lain.

Temuan di atas diperkuat dengan hasil penelitian tentang hubungan antara sikap asertif dan kebahagiaan pada santri remaja yang dilakukan oleh Fitriani. Berdasarkan analisis penelitian diperoleh hasil pada variabel sikap asertif, yaitu ketegori sikap asertif tinggi memiliki prosentase 98,8\% sedangkan sekap asertif sedang 1,2\%. Pada variabel kebahagiaan, yakni kebahagiaan tinggi memiliki prosentase 52,4\%, kategori kebahagiaan sedang 43,9\% dan kategori rendah 3,7\%. Pada hasil analisis uji hipotesis diperoleh hubungan yang signifikan sebesar 0,325 . Hasil penelitian ini membuktikan bahwa perilaku asertif berhubungan positif dengan pencapaian kebahagiaan individu.

Tiga aspek perilaku asertif yaitu : (1) Kesadaran Diri, individu memiliki kesadaran diri yang memadai sehingga dapat mengenali perasaan diri sendiri sebelum mengungkapkannya. (2) Pengendalian diri atau pengendalian nafsu. Individu harus mampu mengendalikan nafsu sehingga dapat mengungkapkan ketidak setujuan atau kemarahan tanpa membiarkan kemarahan menjadi kemarahan sengit, dan mampu menyatakan berbagai keinginan secara tepat, serta dengan intensitas yang tepat. (3) Kemampuan mempertahankan hak-hak pribadi. Individu dapat atau mampu untuk tidak sependapat dengan orang lain tanpa menggunakan sabotase maupun alasan yang emosional, mampu bertahan di jalur yang benar, mempertahankan pendapat diri sendiri sekaligus tetap menghormati pendapat orang lain dan peka terhadap kebutuhan orang lain [6].

Manusia merupakan makhluk ciptaan Allah yang paling sempurna dan Allah SWT menganjurkan kepada hambanya untuk berperilaku tegas dalam menjalani kehidupan terutama dalam menerapkan amar ma'ruf nahi mungkar, berbuat pada kebenaran dan kebaikan mencegah pada kemungkaran, ketegasan itu telah tertulis pada surat Al- Ahzab ayat 70 yang artinya " Hai orang-orang yang beriman, bertaqwalah kamu kepada Allah dan katakanlah perkataan yang benar " [1].

Kemampuan berperilaku asertif menunjukan daya kreatif di setiap penyesuaian diri terkait proses pembelajaran yang memuaskan. Perilaku asertif siswa dinilai tidak cukup terbangun hanya melalui konsep, teori dan diskusi saja pada saat interaksi proses pembelajaran namun perlu latihan dan evaluasi sehingga mampu mendongkrak kompetensi kepribadian siswa.

Dari beberapa hal tersebut perlu adanya latihan dan upaya untuk membangun kemampuan perilaku asertif siswa sehingga dapat membantu siswa secara baik untuk mencapai hasil belajar yang optimal, mampu menyesuaikan diri dengan lingkungannya serta menjadi pribadi yang baik.

Melatih siswa agar berperilaku asertif tidak cukup melalui kegiatan diskusi disetiap proses pembelajaran. Dalam strategi dan layanan pelaksanaan Bimbingan dan Konseling terdapat beberapa layanan yang dapat membantu siswa meningkatkan perilaku asertif, layanan tersebut yaitu layanan bimbingan kelompok. Bimbingan kelompok merupakan suatu layanan yang dapat diberikan kepada sejumlah siswa untuk membahas suatu permasalahan yang diberikan oleh konselor atau permasalahan bebas yang dilaksanakan dalam suasana kelompok dengan melibatkan dinamika kelompok.

Bimbingan kelompok dapat membantu meningkatkan perilaku asertif dikarenakan dalam kegiatan bimbingan kelompok semua anggota kelompok diminta untuk berpendapat, mengeluarkan ide atau pemikirannya untuk membahas topik yang ada. Bimbingan kelompok memiliki tujuan umum dan tujuan khusus, tujuan umumnya adalah berkembangnya kemampuan sosialisasi siswa, khususnya kemampuan komunikasi peserta layanan. Di samping itu bimbingan kelompok juga bertujuan untuk membantu individu menemukan dirinya sendiri, mengarahkan diri, dan dapat menyesuaikan diri dengan lingkungannnya. Sedangkan secara khusus, bimbingan kelompok bertujuan untuk membahas topik-topik tertentu yang mengandung permasalahan aktual (hangat) dan menjadi perhatian peserta [10]. Melalui dinamika kelompok yang intensif, pembahasan topik-topik itu mendorong pengembangan perasaan, pikiran, persepsi, wawasan, sikap yang menunjang diwujudkannya tingkah laku yang lebih efektif.

Penghambat kemauan siswa dalam mengeluarkan ide atau pendapatnya pada pelaksanan bimbingan kelompok adalah kurangnya percaya diri atas apa yang ada dalam 
pikirannya, ketakutan akan kritik dan ejekan yang diberikan oleh teman-temannya ketika mengeluarkan pendapatnya.

Salah satu teknik berpikir kreatif sehingga memberikan jalan untuk berinisiatif kreatif dengan mendorong siswa untuk mencurahkan semua ide yang timbul dari pikirannya dalam jangka waktu tertentu berkenaan dengan beberapa masalah, dan tidak diminta untuk menilainya selama curah pendapat berlangsung adalah metode brainstorming. Metode ini memberikan penilaian khusus yang dilakukan pada periode berikutnya dimana semua ide dipilih, dievaluasi dan mungkin diterapkan [12].

Brainstorming adalah suatu teknik yang digunakan untuk menghasilkan suatu daftar panjang yang berisi berbagai respon berbeda tanpa membuat penilaian terhadap ide-ide individu [2].

Bimbingan kelompok dengan teknik brainstorming dapat meningkatkan rasa percaya diri siswa hal ini sesuai hasil penelitian model bimbingan kelompok dengan teknik brainstorming dapat meningkatkan rasa percaya diri siswa di SMA Negeri 1 Bumiayu Jawa Tengah [3]. Penelitian lain tentang brainstorming dilakukan di kelas komunikasi lisan di SMA Jepang. Penelitian ini menggunakan metode penelitian eksperimen, dilakukan pada enam kelas, setiap kelas yang berjumlah 40 siswa dibagi dua menjadi kelompok kontrol dan kelompok eksperimen. Penelitian tersebut menyatakan bahwa brainstorming memiliki efek positif yang kuat pada suasana kelas dan perilaku siswa [5].

Layanan bimbingan kelompok yang akan diberikan kepada siswa berupa layanan bimbingan kelompok dengan teknik brainstorming, aturan dalam brainstorming menjadi dasar dalam pelaksanaan layanan bimbingan kelompok. Layanan bimbingan kelompok dengan teknik brainstorming diberikan kepada siswa kelas VIII C untuk meningkatkan kemampuan perilaku asertif.

\section{METODE}

Metode dalam penelitian ini adalah quasi experiment design dengan bentuk "one group pre test-post test design". Subjek pada penelitian ini masuk dalam satu kelompok yaitu kelompok eksperimen. Kelompok eksperimen diberi perlakuan berupa kegiatan Bimbingan Kelompok dengan Teknik Brainstorming untuk Meningkatkan Perilaku Asertif. Subjek penelitian adalah 10 siswa SMP Muhammadiyah 1 Kota Magelang.

TABEL I

RANCANGAN PENELITIAN

\begin{tabular}{cccc}
\hline Kelompok & Pretest & Perlakuan & Posttest \\
\hline Eksperimen & $O 1$ & $\mathrm{X}$ & $O 2$ \\
\hline
\end{tabular}

Data yang dikumpulkan dalam penelitian ini adalah perilaku asertif siswa SMP Muhammadiyah 1 Kota Magelang. Konstruk teori yang dikembangkan berdasarkan pada perumusan teori mengenai perilaku asertif Galassi \& Galassi.

Definisi operasional bertujuan membuat konsep secara operasional mengarah kepada penyusunan insrumen penelitian. Efektifitas Bimbingan Kelompok dengan Teknik Brainstorming untuk Meningkatkan Perilaku Asertif, yang peneliti definisikan sebagai berikut:

a. Bimbingan kelompok dengan teknik brainstorming merupakan suatu proses bantuan layanan yang diberikan kepada siswa, agar siswa dapat mengenal pada dirinya, memahami dirinya, berani mengungkapkan perasaan pikiran dan pendapat tanpa adanya tekanan dari orang lain

b. Perilaku asertif mencakup beberapa hal diantaranya dapat mengungkapkan perasaan positif, kemampuan afirmasi diri serta dapat mengungkapkan perasaan negatif pada orang lain.

Teknik dan instrumen pengumpulan data menggunakan teknik wawancara, obeservasi, dan skala perilaku asertif. Skala perilaku asertif disusun dalam bentuk item tertutup. Skala dalam penelitian ini menggunakan metode Likert Summating Rating Scale.

Analisis data yang digunakan dalam penelitian ini analisis Paired Sample t-Test. Analisis dengan menggunakan Paired Sample t-Test dengan pertimbangan dengan penelitian ini menggunakan satu variabel bebas (independent variable), dengan bantuan progam statistik SPSS For Windows Versions 23.0

\section{HASIL DAN PEMBAHASAN}

\section{A. Hasil}

Berdasarkan hasil wawancara dan observasi pada guru bimbingan dan konseling, kegiatan bimbingan kelompok telah dilaksanakan sesuai dengan tahapan dalam pelaksanaannya namun bimbingan kelompok dilaksanakan secara insidental, jika dirasa diperlukan dan dilaksanakan pada saat jam bimbingan dan konseling.

Hasil studi pendahuluan tentang tingkat kemampuan perilaku asertif, peneliti mengambil sebanyak 10 siswa sebagai subjek penelitian secara random sampling, yakni 3 siswa dengan tingkat kemampuan perilaku asertif tinggi, 4 siswa dengan tingkat kemampuan perilaku asertif sedang, 3 siswa dengan tingkat kemampuan perilaku asertif kurang.

Kegiatan bimbingan kelompok dengan teknik brainstorming dilaksanakan selama 6 kali pertemuan di ruang bimbingan dan konseling pada jam pelajaran bimbingan dan konseling dan sepulang sekolah. Selama proses kegiatan bimbingan kelompok pada setiap pertemuan dilakukan evaluasi dan pemberian tugas individu. Evaluasi tiap pertemuan dilakukan secara lisan dan tertulis. evaluasi secara tertulis menggunakan instrument LAISEG (penilaian segera) yang dikembangkan oleh peneliti dan disesuaikan pada setiap pertemuan.

Jenis kelompok yang digunakan dalam penelitian ini adalah kelompok tugas, yakni pelaksanaan bimbingan kelompok dengan membahas topik-topik tertentu yang diberikan oleh pemimpin kelompok. Topik yang dibahas dalam bimbingan kelompok dikaitkan dengan 3 aspek kemampuan perilaku asertif menurut Galasi \& Galasi yang meliputi kemampuan mengungkapkan perasaan positif, kemampuan afirmasi diri dan kemampuan mengungkapkan perasaan negatif. Ketiga aspek tersebut dijabarkan dalam 
beberapa tema pembahasan dan tugas individu yang saling berkesinambungan sehingga diharapkan setelah mengikuti serangkaian kegiatan bimbingan kelompok siswa paham mengenai perilaku asertif, mampu berperilaku dan mempertahankan perilaku asertif serta meningkatkan perilaku asertif.

Untuk mengetahui pengaruh atau dampak pemberian treatment layanan bimbingan kelompok dapat dilihat melalui grafik perbedaan evaluasi awal (pretest) dan evaluasi akhir (post test)

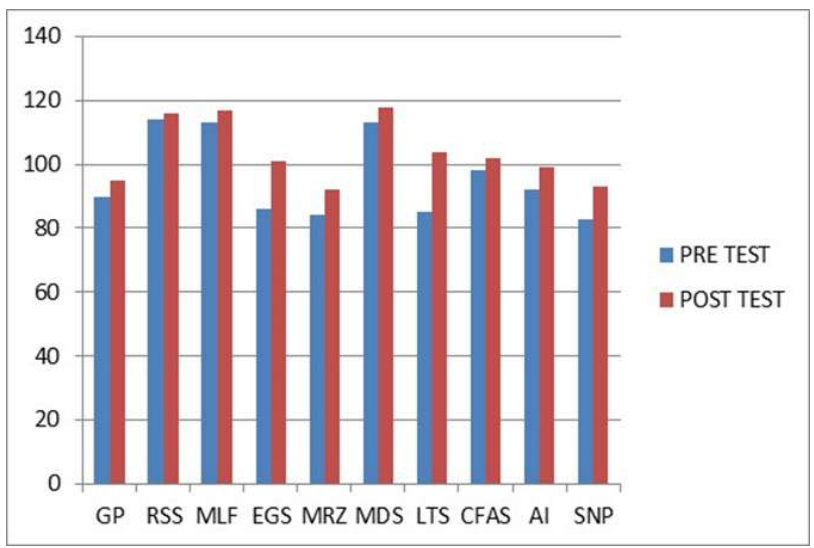

Gambar 1. Grafik Pre test-Post test

Berdasarkan grafik di atas dapat diamati bahwa kemampuan perilaku asertif pada anggota kelompok mengalami peningkatan (nilai post-test lebih tinggi daripada nilai pre-test). Ketercapaian hasil tersebut karena treatment berupa layanan bimbingan kelompok dengan teknik brainstorming dilaksanakan dengan sungguh-sungguh sesuai dengan prosedur yang telah direncanakan, walaupun terjadi beberapa hambatan saat kegiatan berlangsung.

Uji keefektifan layanan bimbingan kelompok dengan teknik brainstorming untuk meningkatkan kemampuan perilaku asertif siswa dianalisis dengan paired samples test. Berikut disajikan hasil uji efektifitas layanan bimbingan kelompok yang dikembangkan untuk meningkatkan kemampuan perilaku asertif siswa, dengan menggunakan bantuan perangkat lunak SPSS 23.0 for windows.

TABEL II

UJI T-TEST PRE TEST DAN POST TEST KEMAMPUAN PERILAKU ASERTIF SISWA

\begin{tabular}{lcccc}
\hline Pengukuran & Mean & $\begin{array}{c}\text { Std. } \\
\text { Dev }\end{array}$ & t & df \\
\hline $\begin{array}{l}\text { Pre test - Post } \\
\text { Test }\end{array}$ & -7.90000 & 5.38413 & -4.640 & 9 \\
\hline
\end{tabular}

Hasil uji beda menunjukkan bahwa siswa mengalami peningkatan dalam kemampuan berperilaku asertif. Berdasarkan analisis data hipotesis terbukti bahwa pelaksanaan bimbingan kelompok dengan teknik brainstorming mampu meningkatkan kemampuan perilaku asertif siswa. Hal ini dibuktikan dari nilai t hitung masingmasing aspek yang lebih besar daripada t-table, dan berdasarkan nilai signifikansi seluruh aspek mempunyai nilai signifikansi $<0,05$. Berdasarkan uji $\mathrm{T}_{-}{ }_{\text {Test }}$ diperoleh $\mathrm{t}_{{ }_{\text {hitung }}}=-$ $4.640 \leq \mathrm{t}^{-}{ }_{\text {tabel }}=-2.262$, sehingga Ho ditolak dan Ha diterima dengan kata lain bimbingan kelompok dengan teknik brainstorming efektif untuk meningkatkan kemampuan perilaku asertif siswa.

\section{B. Pembahasan}

Hubungan antara asertif dan kecemasan berdampak pada kesehatan mental, proses pelaksanaan pendidikan dan kehidupan sehari-hari. Siswa hendaknya diberikan pelatihan dengan membekali ketrampilan yang diperlukan untuk berinteraksi dengan orang lain, meningkatkan asertif dan mengurangi kecemasan. Penelitian serupa tentang The Enhancement Of Assertive Behavior Through Psychodrama Techniques Of The Students In Class VII D In Junior High School State 2 Moyudan (2017). Penelitian ini berhasil meningkatkan perilaku asertif dengan teknik psikodrama untuk anak tingkat SMP [11].

Perilaku asertif berpengaruh pada kebahagiaan seseorang dalam menjalani kehidupan sehari-hari. Perilaku asertif akan muncul pada saat orang melakukan hubungan interpersonal dengan orang lain. Pada saat proses hubungan akan timbul rasa nyaman pada kedua belah pihak.

Kemampuan perilaku asertif siswa di lapangan masih terlihat rendah, hal ini terbukti dengan masih adanya perilaku siswa yang menyimpang dari norma masyarakat. Perilaku asertif menuntut siswa untuk berani mengatakan hal yang sebenarnya, sejujurnya sesuai dengan kata hatinya walaupun bertentangan dengan keinginan orang lain. Beberapa permasalahan kenakalan remaja di lapangan bersumber dari kemampuan bersikap asertif yang rendah, misalnya perkelahian antar pelajar, pergaulan bebas, menurunnya kualitas pembelajaran dan pendidikan serta memudarnya pemahaman pengamalan nilai-nilai islam.

Agama Islam mengajarkan kepada ummat manusia untuk selalu berbuat baik kepada orang lain, berbuat amar ma'ruf nahi mungkar yaitu seruan kepada manusia untuk selalu berbuat kebaikan dan mencegah kemungkaran. Islam mengajarkan ummatnya untuk selalu berbicara dengan benar, mengungkapkan perasaan-perasaan positif dan berbuat secara tegas. Senada dengan pengertian perilaku asertif yaitu berkomunikasi dengan tepat dan tegas namun tidak mengabaikan hak orang lain serta menyakiti perasaan orang lain.

Allah SWT berfirman dalam Al-Qur'an Surat Al- Ahzab ayat 70 yang artinya "Hai orang-orang yang berfirman, bertaqwalah kamu kepada Allah dan katakanlah perkataan yang benar". Setiap orang yang beragama Islam dianjurkan untuk berbuat tegas terutama dalam menerapkan perilaku amar ma'ruf nahi mungkar.Allah SWT memerintahkan untuk berkata benar dan tegas serta hal-hal yang kita anggap benar atau salah [1].

Perintah Rasulullah SAW pada umatnya untuk mengembangkan budaya berani mengungkapkan pendapat dikalangan sahabat dan umatnya [8].

Dengan memberikan layanan bimbingan kelompok dengan teknik brainstorming kemampuan perilaku asertif 
siswa dapat ditingkatkan. Metode brainstorming atau curah pendapat memiliki efek positif pada prestasi pendidikan siswa [4].

Menurut Osborn teknik brainstorming memiliki empat aturan dasar yaitu (1) Tidak diperkenankan menilai atau mengkritik ide yang dicetuskan (2) Bebaskan diri, semakin aneh atau liar suatu ide maka semakin baik (3) Utamakan jumlah, semakin banyak ide yang muncul maka akan semakin baik (4) Bangun ide baru dari ide-ide yang sudah disampaikan anggota lain [9].

Dengan memadukan teknik brainstorming dalam pelaksanaan bimbingan kelompok memberikan pengaruh terhadap kemampuan perilaku asertif siswa, akan tetapi hal tersebut masih perlu dilakukan latihan secara terus menerus sehingga siswa terbiasa untuk berperilaku asertif.

\section{KESIMPULAN}

Layanan bimbingan kelompok sudah dilaksanakan di SMP Muhammadiyah 1 Kota Magelang melalui 4 tahapan, yakni tahap pembentukan, peralihan, kegiatan, dan pengakhiran. Teknik brainstorming belum pernah digunakan dalam layanan bimbingan kelompok untuk meningkatkan kemampuan perilaku asertif.

Bimbingan kelompok dengan teknik brainstorming efektif untuk meningkatkan kemampuan perilaku asertif.

\section{UCAPAN TERIMAKASIH}

Ucapan terima kasih disampaikan kepada Guru Bimbingan dan Konseling SMP Muhammadiyah 1 Kota Magelang.

\section{DAFTAR PUSTAKA}

[1] Departemen Agama RI. (2002). Al-Qur'an dan terjemahannya. Jakarta : Al Huda.

[2] Barbara, A. \& Freeman, S. (2010). Menjadi Guru Kreatif. Yogjakarta: Golden Book.

[3] Alfiah, K. (2014). Pengembangan Model Bimbingan Kelompok dengan Teknik Brainstorming untuk Meningkatkan Kepercayaan Diri Siswa di SMA Bumiayu Jawa Tengah. Tesis. Sekolah Pascasarjana UNNES: Semarang.

[4] Cobra, E.R., Mojtaba, N., Faribaani, H., \& Shahla, D. (2013). The Effect of the Using the Brainstorming Method on the Academic Achievement of Student in Grade Five in Tehran Elementary School. Journal Procedia Social and Behavioral Sciences, 83, 230-233.

[5] Cullen, B. (2008). Brainstorming Before Speaking Tasks: The Internet TESL Journal, IV (7) July.

[6] Galassi, M.D., \& Galassi, J.P. (1977). Assess Your Self : How to be Your Own Person. New York : Human Sciences Press.

[7] Hurlock, E. (1995). Psikologi perkembangan suatu pendekatan sepanjang rentang kehidupan. Jakarta: Erlangga.

[8] Najati, M.U. (2003). Psikologi Dalam Tinjauan Hadits Nabi. Jakarta : Mustaqim.

[9] Osborn, A.F. (1963). Applied Imagination : Principles and Procedures of Creative Problem Solving (Third Revised Edition). New York

[10] Prayitno. (2004). Layanan Bimbingan dan Konseling Kelompok, Seri Layanan Konseling. Padang : UNP
[11] Ribha, S. (2017). The Enhancement Of Assertive Behavior Through Psychodrama Techniques Of The Students In Class VII D In Junior High School State 2 Moyudan. E-Journal Bimbingan dan Konseling.

[12] Stein, J.S., \& Howard. (2002). Ledakan EQ. Bandung: CV. Alfabeta 